\title{
PERANAN KOMPETENSI PEGAWAI MEMEDIASI PENGARUH PENDIDIKAN DAN PELATIHAN (DIKLAT) TERHADAP EFEKTIVITASORGANISASI
}

\author{
Kadek Ayu Anggreni ${ }^{1}$ \\ I Komang Ardana ${ }^{2}$ \\ ${ }^{1,2}$ Fakultas Ekonomi dan Bisnis Universitas Udayana (Unud), Bali, Indonesia \\ email:ayuanggrenikdk@yahoo.com
}

\begin{abstract}
ABSTRAK
Penelitian ini bertujuan untuk menganalisis peranan kompetensi pegawai memediasi pengaruh pendidikan dan pelatihan (diklat) terhadap efektivitas organisasi. Sampel yang diambil sebanyak 80 responden yaitu pegawai Dinas Perdagangan dan Perindustrian provinsi Bali yang sudah mengikuti pendidikan dan pelathan (diklat) sebelumnya sedangkan teknik analisis yang digunakan adalah Path Analysis.Berdasarkan hasil analisis ditemukan bahwa pendidikan dan pelatihan (diklat) berpengaruh positif dan signifikan terhadap kompetensi pegawai dan berpengaruh positif dan signifikan terhadap efektivitas organisasi. Kompetensi pegawai berpengaruh positif dan signifikan terhadap efektivitas organisasi. Hasil penelitian ini juga membuktikan bahwa kompetensi pegawai secara positif dan signifikan memediasi pengaruh pendidikan dan pelatihan (diklat) terhadap efektivitas organisasi. Implikasi teoritis hasil penelitian ini memperjelas pengaruh variabel pendidikan dan pelatihan (diklat) terhadap efektivitas organisasi yang dimediasi kompetensi pegawai,. Penelitian ini menunjukkan bahwa peran program pendidikan dan pelatihan (diklat) akan meningkatkan efektivitas organisasi yang didukung oleh kompetensi pegawai yang tinggi.
\end{abstract}

Kata kunci: pendidikan, pelatihan, kompetensi, efektivitas organisasi

\begin{abstract}
This study aims to analyze the role of employee competencies to mediate the influence of education and training (diklat) on organizational effectiveness. Samples were taken as many as 80 respondents, namely employees of the Trade and Industry Office of the province of Bali who had attended education and training before while the analysis technique used was Path Analysis. Based on the results of the analysis found that education and training had a positive and significant effect on competence. employees and have a positive and significant effect on organizational effectiveness. Employee competence has a positive and significant effect on organizational effectiveness. The results of this study also prove that employee competence positively and significantly mediates the influence of education and training (diklat) on organizational effectiveness. Theoretical implications of the results of this study clarify the influence of education and training (training) variables on organizational effectiveness mediated by employee competence. This study shows that the role of education and training programs (diklat) will improve organizational effectiveness supported by high employee competencies.
\end{abstract}

Keywords: education, training, competence, organizational effectiveness 


\section{PENDAHULUAN}

Di Indonesia saat ini banyak organisasi modern. Salah satu ciri dari organisasi modern ini adalah memiliki tingkat persaingan yang tinggi dalam hal tingkat kompleksitas dan ambiguitas. Organisasi modern harus bersifat terbuka, terutama terbuka dengan perubahan-perubahan yang ada di lingkungan sekitar. Organisasi modern ini meliputi interaksi proses, bagian dan fungsi dalam suatu organisasi, baik antar organisasi lain maupun antarinternal organisasi.

Organisasi-organisasi modern ini berkembang karena berbagai faktor-faktor eksternal, seperti globalisasi, teknologi, dan perubahan demografis, sehingga menuntut organisasi modern untuk tetap bersikap inovatif guna meningkatkan daya saing (Whitfield and Landeros, 2006). Para pemimpin instansi secara tidak langsung dituntut untuk memeriksa kembali dan membangun taktik organisasi mereka agar bisa menjadi organisasi yang efektif (Whitfield dan Landeros, 2006) dan memeriksa kembali unsur pegawai yang ada dalam instansi mereka, peranan pegawai sangat penting dalam menggerakkan suatu organisasi (Ardana dkk, 2012).

Menurut Subkhi \& Jauhar (2013:263) efektivitas organisasi merupakan kombinasi efektivitas antar individu, kelompok dan organisasi itu sendiri dilihat secara kelembagaan. Efektivitas organisasi adalah tingkat ketepatan dalam pencapaian suatu sasaran dengan memanfaatkan sumber daya yang ada (Mohyi, 2012:197). Ukuran dari organisasi efektif adalah keberhasilan organisasi dalam mencapai tujuan dan sasaran yang telah dibuat oleh organisasi tersebut (Darsono \& Siswandoko, 2011:294). Kurang efektifnya pengelolaan organisasi terlihat dari kurang maksimalnya efektivitas individu-individu yang ada didalamnya 
(Oktaviana dan Hendriani, 2017). Efektivitas organisasi menjadi kurang optimal juga disebabkan oleh ketidaksesuaian status peran dengan kompetensi yang dimiliki oleh pegawai (Oktaviana dan Hendriani, 2017).

Sutrisno (2010:125) mengatakan bahwa praktek manajemen yang mempengaruhi efektivitas organisasi salah satunya adalah aspek pendidikan dan pelatihan. Pada sejumlah sektor publik, pendidikan dan pelatihan pada pegawai berpengaruh terhadap efektivitas organisasi (Anike \& Ekwe 2014). Pendidikan dan pelatihan (Diklat) adalah suatu kegiatan yang dilakukan oleh instansi sebagai upaya untuk meningkatkan kemampuan, keterampilan, prestasi atau kinerja pegawainya dan pada akhirnya akan berpengaruh terhadap efektivitas organisasi (Yuniartidkk., 2013).Manullang (2008:66) mengatakan bahwa pendidikan dan pelatihan (Diklat) pegawai adalah persyaratan dalam suatu pekerjaan yang dapat ditentukan dengan keahlian dan pengetahuan yang dimiliki seorang pegawai berdasarkan aktivitas yang dilaksanakan pada pekerjaannya. Manfaat yang didapat dengan adanya pendidikan dan pelatihan (Diklat) bagi efektivitas organisasi adalah dapat meningkatkan kepuasan kerja, meningkatkan motivasi kerja, meningkatkan efisiensi dalam proses dan mengembangkan sikap inovasi para pegawai (McNamara, 2010). Kunartinah dan Sukoco (2010) mengatakan bahwa Pendidikan dan pelatihan (Diklat) berkaitan dengan usaha untuk mempersiapkan calon tenaga kerja yang diperlukan oleh suatu instansi atau organisasi sehingga cara penekanannya pada kemampuankognitif, afektif dan psikomotor.

Penelitian dari Moses (2011) mengatakan bahwa ada hubungan yang positif antara pendidikan dan pelatihan (Diklat) dan prestasi kerja. Dalam hal ini, jenis 
pelatihan, materi pelatihan dan waktu pelaksanaan pelatihan bila diberikan dengan baik maka akan berpengaruh terhadap kompetensi pegawai. Jika kompetensi pegawai meningkat, maka secara tidak langsung membuat prestasi kerja setiap pegawainya juga akan meningkat. Penelitian dari Jehanzeb \& Bashir (2013) juga mengatakan bahwa pendidikan dan pelatihan (Diklat) membawa manfaat peningkatan kompetensi bagi individu dan manfaat peningkatan efektivitas organisasi bagi sebuah organisasi atau instansi.

Lastanti (2005) mengatakan bahwa kompetensi adalah ketrampilan dari seorang ahli. Dalam hal ini, didefinisikan sebagai seseorang yang memiliki tingkat keterampilan tertentu atau pengetahuan yang tinggi dalam subyek tertentu yang diperoleh dari pelatihan dan pengalaman. Setiap instansi harus meningkatkan tingkat pengetahuan, tingkat keterampilan dan perilaku kerja pada setiap pegawainya (Markovic, 2008). Kompetensi dapat memiliki nilai yang berbeda, jika dilihat dari penilaian diri, penilaian eksternal atau kombinasi dari keduanya (Leinweber, 2013). Menurut Rauner et al. (2013:19), kompetensi yang bersifat profesional mampu mengetahui kemampuan dan keterampilan yang dimiliki oleh setiap pegawainya sehingga para pegawai bisa mempraktikannya dalam pekerjaan mereka, tujuannya adalah agar para pegawai dapat mengidentifikasi dan mengembangkan potensi mereka untuk organisasi atau instansi tempat mereka bekerja.

Secara umum, kompetensi lebih menekankan pada perilaku produktif yang harus dimiliki serta diperagakan oleh seseorang dalam melaksanakan suatu pekerjaan agar dapat berprestasi luar biasa (Parulian dan Thoha, 2008:5). Menurut 
Mangkunegara(2009:111) kompetensi SDM yang perlu dimiliki oleh mereka yang ingin berkarir di bidang sumber daya manusia yang paling mendasar (fundamen) adalah mereka mampu menguasai sistem informasi kepegawaian, memiliki motivasi yang tinggi, kreatif, selalu bersikap inovatif, berkepribadian dewasa, dan memiliki kecerdasan emosi yang baik.

Sutrisno (2010:125) mengatakan bahwa kompetensi adalah salah satu variabel yang mempengaruhi efektivitas organisasi. Analisis faktor yang menjelaskan bahwa keunggulan kompetitif dari suatu organisasi atau instansi adalah dari kompetensi individu atau setiap kompetensi yang dimiliki oleh setiap pegawai di suatu instansi. Penelitian Nurmanah (2009) juga mengatakan bahwa kompetensi berhubungan kuat dan positif dengan efektivitas organisasi. Penelitian Nair (2007) mengatakan bahwa organisasi dituntut mengelola kompetensi agar dapat meningkatkan efisiensi dan efektivitas organisasi.

Pentingnya program pendidikan dan pelatihan (Diklat) dalam suatu organisasi atau instansi adalah untuk memelihara peningkatan kompetensi bagi setiap pegawainya guna mencapai efektivitas organisasi (Oktaviana dan Hendriani, 2017). Jadi pelaksaan rekruitmen dan seleksi pegawai harus dilaksanakan secara the whole person dengan the whole job, karena penerapan konsep kompetensi dalam perekrutan dan seleksi merupakan cara yang tepat untuk memperoleh SDM yang berkualitas dan tepat (Sujanto, 2009). Potnuru and Sahoo(2016), mengatakan bahwa belum ada penelitian yang secara khusus membahas tentang bagaimana perbedaan kompetensi yang dimiliki setiap pegawai dan dikembangkan langsung oleh pegawai tersebut dengan cara berpartisipasi 
dalam pendidikan dan pelatihan (Diklat) yang berpengaruh terhadap peningkatan efektivitas organisasi.

Dinas Perdagangan dan Perindustrian Provinsi Bali memiliki tugas pokok dan fungsi untuk melaksanakan sebagian urusan rumah tangga daerah dalam bidang perdagangan dan perindustrian, memberdayakan usaha kecil menengah yang berkaitan dengan kerajinan di seluruh Bali serta memberdayakan industri kecil menengah di seluruh Bali. Pemberdayaan industri kecil menengah di Bali, telah dilakukan oleh Dinas Perdagangan dan Perindustrian provinsi Bali tetapi belum mencapai hasil yang maksimal. Hal ini dapat dilihat dari data kinerja IKM Bali:

Tabel 1.

Kinerja IKM Bali Tahun 2012-2017

\begin{tabular}{ccc}
\hline Tahun & Unit Usaha & Tenaga Kerja (orang) \\
\hline 2013 & 11.905 & 92.959 \\
2014 & 12.084 & 92.997 \\
2015 & 12.326 & 93.180 \\
2016 & 12.730 & 96.601 \\
2017 & 14.992 & 103.969 \\
\hline
\end{tabular}

Sumber: Dinas Perdagangan dan Perindustrian provinsi Bali, 2018

Dari Tabel 1 secara umum dapat dilihat bahwa IKM Bali terus mengalamai peningkatan. Peningkatan ini terjadi karena target yang diberikan Dinas Perdagangan dan Perindustrian provinsi Bali terhadap IKM Bali relatif stabil bahkan dapat dikatakan selalu tetap dari tahun ke tahun. Kondisi ini, mengindikasikan bahwa adanya rasa pesimis dari Dinas Perdagangan dan Perindustrian provinsi Bali dalam meningkatkan target yang ingin dicapai pada periode mendatang. Hal ini bisa terjadi, karena persaingan yang ketat dan tidak 
E-Jurnal Manajemen, Vol. 8, No. 5, 2019 : 2781-2808

diimbangi oleh profesionalisme dalam organisasi, sehingga ada indikasi bahwa efektivitas dalam organisasi ini masih kurang. 
Tabel 2.

Nilai Ekspor Seluruh Bali

\begin{tabular}{cc}
\hline Tahun & Nilai Ekspor Seluruh Bali \\
\hline 2013 & $486.063 .655,35$ \\
2014 & $503.826 .213,14$ \\
2015 & $481.402 .783,80$ \\
2016 & $574.276 .900,25$ \\
2017 & $679.594 .478,52$ \\
\hline
\end{tabular}

Sumber: Dinas Perdagangan dan Perindustrian provinsi Bali, 2018

Dari Tabel 2 Nilai Ekspor seluruh Bali mengalami fluktuasi karena permintaan akan produk ekspor diluar negeri sulit untuk diprediksi. Hal ini disebabkan karena kurangnya pengetahuan pegawai terhadap perkembangan pasar yang ada luar negeri. Perkembangan ini sesungguhnya bisa diprediksi dengan baik jika dalam organisasi didukung oleh pegawai yang memiliki kompetensi yang sesuai dalam bidangnya. Oleh karena itu, diduga bahwa penyebab dari fluktuasi nilai ekspor ini selain dari perubahan eksternal tetapi juga adanya permasalahan dari efektivitas dalam organisasi tersebut. Untuk itu perlu dilakukankanya pendidikan dan pelatihan (Diklat) terhadap pegawai sehingga dapat meningkatkan kompetensi pegawai terutama dalam membaca perkembangan yang ada di pasar luar negeri sehingga dapat memberikan peningkatan pada efektivitas dalam organisasi tersebut.

Dinas Perdagangan dan Perindustrian Provinsi Bali merupakan salah satu instansi pemerintah provinsi Bali yang sedang giat melakukan pendidikan dan pelatihan (Diklat) guna meningkatkan efektivitas organisasi. 
Tabel 3.

Jumlah Pegawai Dinas Perdagangan dan Perindustrian Provinsi Bali Yang Dikirim Untuk Mengikuti Program Pendidikan dan Pelatihan (Diklat)

\begin{tabular}{cccc}
\hline No & Bulan & $\begin{array}{c}\text { Jumlah Pegawai Yang Dikirim } \\
\text { Mengikuti Diklat Tahun 2016 } \\
\text { (orang) }\end{array}$ & $\begin{array}{c}\text { Jumlah Pegawai Yang Dikirim } \\
\text { Mengikuti Diklat Tahun 2017 } \\
\text { (orang) }\end{array}$ \\
\hline 1 & Januari & 3 & 5 \\
2 & Pebruari & 4 & 6 \\
3 & Maret & 3 & 4 \\
4 & April & 3 & 3 \\
5 & Mei & 4 & 6 \\
6 & Juni & 2 & 6 \\
7 & Juli & 4 & 5 \\
8 & Agustus & 5 & 5 \\
9 & September & 3 & 5 \\
10 & Oktober & 4 & 4 \\
11 & Nopember & 3 & 3 \\
12 & Desember & 3 & 3 \\
\hline
\end{tabular}

Sumber:Bagian kepegawaian Dinas Perdagangan dan Perindustrian Provinsi Bali, 2018

Tabel 3 menunjukkan jumlah pegawai Dinas Perdagangan dan Perindustrian provinsi Bali yang mengikuti pendidikan dan pelatihan (Diklat)dari bulan Januari sampai bulan Desember. Pegawai yang dilibatkan dalam pendidikan dan pelatihan (Diklat)disesuaikan dengan bidang pekerjaan masing-masing. Hanya PNS saja yang dikirim untuk mengikuti pendidikan dan pelatihan (Diklat).

Berdasarkan wawancara awal dengan 15 orang pegawai Dinas Perdagangan dan Perindustrian Provinsi Bali yang telah mengikuti Diklat sebelumnya, maka 11 orang pegawai mengatakan bahwa pendidikan dan pelatihan (Diklat) memberikan dampak pada penyelesaian tugas yang diberikan, sedangkan 4 orang pegawai mengatakan pendidikan dan pelatihan (Diklat)tidak memberikan dampak pada penyelesaian tugas yang diberikan oleh instansi. 
Pendidikan dan pelatihan (Diklat) adalah suatu kegiatan yang dilakukan oleh instansi sebagai upaya untuk meningkatkan kemampuan, keterampilan, kinerja dan prestasi pegawainya (Yuniarti, dkk. 2013). PenelitianMursidi (2009), menjelaskan bahwa pendidikan dan pelatihan (Diklat) merupakan proses yang berlanjut tidak hanya proses yang sesaat terutama disaat perkembangan teknologi dan pengetahuan semakin berkembang pesat seperti sekarang, peran pendidikan dan pelatihan (Diklat) adalah sebagai bekal pegawai agar bisa menjadi pegawai yang lebih kreatif dalam mencapai tujuan organisasi secara efektif dan efisien. Manullang (2008:66) mengatakan bahwa pendidikan dan pelatihan (Diklat) pegawai adalah persyaratan dalam suatu pekerjaan yang dapat ditentukan dengan keahlian dan pengetahuan yang dimiliki seorang pegawai berdasarkan aktivitas yang dilaksanakan pada pekerjaannya. Jadi pendidikan dan pelatihan (Diklat) pegawai merupakan suatu persyaratan pekerjaan untuk memperbaiki penguasaan berbagai keterampilan, keahlian dan pengetahuan berdasarkan aktivitas kerja yang sesungguhnya secara terinci dan rutin agar dapat menjalankan dan menyelesaikan pekerjaan yang diberikan kepadanya.

Handoko (2001:103), tujuan yang ingin dicapai oleh organisasi dalam melaksanakan pendidikan dan pelatihan (Diklat) adalah untuk menutup antara kecakapan dan kemampuan pegawai dalam permintaan jabatan. Kedua, programprogram Diklat diharapkan dapat meningkatkan kerja pegawai yang semakin efektif dan efisien dengan mencapai sasaran-sasaran kerja yang sudah ditetapkan. Dari penjelasan tersebut, dapat disimpulkan bahwa tujuan dari Diklat adalah agar meningkatnya kemampuan kerja pegawai instansi dengan cara memperbaiki 
efisiensi dan efektivitas kerja pegawai dalam instansi sehingga dapat mencapai hasil-hasil kerja yang telah ditetapkan.

Prinsip-prinsip umum diperlukan saat instansi mengadakan pendidikan dan pelatihan (Diklat). Prinsip-prinsip itu digunakan sebagai pedoman dalam melaksanakan dan merencanakan pendidikan dan pelatihan (Diklat) agar berjalan dengan baik dan berhasil. Yoder (2000) prinsip-prinsip pendidikan dan pelatihan (Diklat) antara lain : 1) Perbedaan Individu (Individual Differences). Dalam pendidikan dan pelatihan (Diklat) didasari dengan adanya perbedaan potensi dalam tiap peserta, karena perbedaan tersebut adalah hal yang perlu diperhatikan untuk merencanakan program pendidikan dan pelatihan (Diklat). 2) Hubungan dengan Analisis Jabatan (Relation to Job Analysis). Setiap pekerjaan membutuhkan kejelasan dengan pengetahuan dan kecakapan apa saja yang diperlukan seorang pekerja untuk mengerjakan tugasnya dengan baik. Materi yang diberikan pada saat pendidikan dan pelatihan (Diklat) harus sesuai dengan apa yang dibutuhkan. 3) Motivasi (Motivation). Rencana dalam sebuah pendidikan dan pelatihan (Diklat) harus didasari dengan adanya semangat dari peserta pendidikan dan pelatihan (Diklat). 4) Partisipasi yang Aktif (Active Participation). Dalam mengikuti pendidikan dan pelatihan (Diklat) peserta dituntut aktif dalam mengemukakan pendapat, memberi pertanyaan atau memberi saran, agar terjadi komunikasi dua arah dalam program pendidikan dan pelatihan (Diklat) tersebut. 5) Metode Pelatihan (Training Methods). Metode yang digunakan dalam program pendidikan dan pelatihan (Diklat) akan menentukan keberhasilan dalam program tersebut. 6) Prinsip Belajar (Principle of Learning). Pembahasan materi dari hal 
yang sederhana sampai hal yang sulit merupakan asas belajar yang digunakan dalam pendidikan dan pelatihan (Diklat).

Kunartinah dan Sukoco (2010) mengatakan bahwa pendidikan dan pelatihan (Diklat) memiliki pengaruh positif dan signifikan terhadap kompetensi. Menurut Purnomo dkk. (2016) juga mengatakan bahwa pendidikan dan pelatihan (Diklat) memiliki pengaruh terhadap kompetensi dengan nilai koefisien regresi sebesar 0,802 yang artinya pendidikan dan pelatihan (Diklat) memiliki pengaruh sebesar 80,2\% terhadap kompetensi dan sisanya 19,8\% dipengaruhi oleh variabel lain yang tidak diteliti pada penelitian ini. Penelitian dari Priansa (2014:258) mengatakan bahwa pendidikan dan pelatihan (Diklat) merupakan salah satu cara untuk memperoleh kompetensi di dalam organisasi.

Dalam human resources development, nilai-nilai kompetensi seorang pegawai dapat dicapai melalui program pendidikan, pengembangan atau pelatihan yang berorientasi pada tuntutan kerja actual dengan penekanan pada pengembangan skill, knowledge and ability yang secara signifikan akan dapat memberikan standar perilaku dalam sistem dan proses kerja yang diterapkan (Irianto 2001:75). Penelitian dari Jehanzeb \& Bashir (2013) juga mengatakan bahwa pendidikan dan pelatihan (Diklat) membawa manfaat peningkatan kompetensi bagi individu dan manfaat peningkatan efektivitas organisasi bagi sebuah organisasi atau instansi. Berdasarkan hal tersebut hipotesis yang dapat dikembangkan dalam penelitian ini adalah:

$\mathrm{H}_{1}$ : Pendidikan dan pelatihan (Diklat) berpengaruh positif dan signifikan terhadap kompetensi pegawai. 
Menurut McNamara (2010) manfaat yang didapat dengan adanya pendidikan dan pelatihan (Diklat) bagi efektivitas organisasi adalah dapat meningkatkan kepuasan kerja pegawai, meningkatkan motivasi kerja, meningkatkan efisiensi dalam proses dan mengembangkan sikap inovasi. Menurut Oktaviana dan Hendriani (2017), mengatakan bahwa pelaksanaan Diklat mempengaruhi keefektifan organisasi secara signifikan, meningkatnya efektivitas organisasi tergantung dari efektif atau tidaknya pelaksanaan Diklat yang dilakukan oleh setiap organisasi atau instansi. Sutrisno (2010:125), mengatakan bahwa salah satu praktek manajemen yang mempengaruhi efektivitas organisasi adalah aspek pelatihan. Penelitian sebelumnya dari Anike dan Ekwe (2014) juga mengatakan bahwa pendidikan dan pelatihan (Diklat) berpengaruh positif terhadap efektivitas organisasi. Berdasarkan hal tersebut hipotesis yang dapat dikembangkan dalam penelitian ini adalah:

$\mathrm{H}_{2}$ : Pendidikan dan pelatihan (Diklat) berpengaruh positif dan signifikan terhadap efektivitas organisasi

Menurut Lawler dan Ledford (1997:231) ketika sebuah organisasi memiliki strategi yang tepat dan pegawai yang kompeten, yang sesuai dengan perubahan lingkungan bisnis maka dianggap sebagai organisasi yang efektif. Banyak faktor yang harus diantisipasi dalam pencapaian hasil strategis seperti kohesi, komunikasi, koordinasi, komitmen, dan peningkatan kompetensi yang sesuai (Cartwright dan Baron, 2002). Menurut Nilsson dan Ellstrom (2012) mengatakan bahwa mengembangkan strategi HRD dalam sebuah organisasi adalah kesempatan bagi pegawai untuk memperkaya kompetensi mereka yang berkontribusi secara keseluruhan terhadap efektivitas organisasi.. Hal ini dianggap 
sangat penting bagi efektivitas organisasi karena dapat meningkatan kinerja pegawai, produktivitas yang lebih tinggi dan membantu dalam membangun kompetensi inti dalam sebuah organisasi (Tarique and Schuler, 2010).

Menurut Lee (2010), mengatakan bahwa ada pemahaman yang berkembang tentang pengembangan dan manajemen kompetensi merupakan instrumen penting untuk meningkatkan Organizational effectiveness (Efektivitas Organisasi). Kompetensi pegawai berperan penting dalam meningkatkan kinerja dan efektivitas organisasi (Naquin dan Holton, 2006).Kompetensi akan memungkinkan organisasi menghasilkan keunggulan kompetitifnya (Fernandez et al., 2014). Penelitian Nurmanah (2009) juga mengatakan bahwa kompetensi berhubungan kuat dan positif terhadap efektivitas organisasi. Berdasarkan hal tersebut hipotesis yang dapat dikembangkan dalam penelitian ini adalah:

$\mathrm{H}_{3}$ : Kompetensi pegawai berpengaruh positif dan signifikan terhadapEfektivitas Organisasi

Menurut Oktaviana dan Hendriani (2017), mengatakanbahwa dengan adanyamediasi dari kompetensi, maka efektivitasorganisasi menjadi lebih baik sebagaiakibat dari pelaksanaan Diklat yangefektif maka peranankompetensi dikatakan mampu menjadi faktormediasi bagi pengaruh Diklat terhadapefektivitas organisasi.Menurut Jehanzeb \& Bashir(2013), mengatakan bahwa pendidikan dan pelatihan (Diklat) membawa manfaat bagi individu berupapeningkatan kompetensi dan bagiorganisasi berupa peningkatan efektivitasorganisasi. Pelaksanaan Diklat di organisasi harusmampu mendorong terjadinyapeningkatan pada pengetahuan,keterampilan dan perilaku kerja pegawaisehingga sejalan dengan pencapaiantujuan organisasi secara efektif. Kompetensi bisa menjadi 
variabel mediasi bagi pengaruh Diklat terhadap efektivitas organisasi karena dengan adanya kompetensi dari pegawai maka efektivitas dalam sebuah organisasi akan berjalan lebih baik sebagai akibat dari pelaksanaan Diklat yang efektif (Potnuru dan Sahoo, 2016). Berdasarkan hal tersebut hipotesis yang dapat dikembangkan dalam penelitian ini adalah:

$\mathrm{H}_{4}$ : Peranan positif dan signifikan dari kompetensi dalam memediasi pengaruh pendidikan dan pelatihan (Diklat) terhadap efektivitas organisasi.

\section{METODE PENELITIAN}

Lokasi penelitian ini dilakukan di Dinas Perdagangan dan Perindustrian Provinsi Bali yang berlokasi di Jalan Raya Puputan Komplek Niti Mandala Renon. Tempat ini dipilih sebagai tempat penelitian karena sedang diintensifkannya pendidikan dan pelatihan (Diklat) di instansi tersebut sehingga perlu dikaji apakah ada pengaruhnya bagi efektivitas organisasi.

Variabel eksogen dalam penelitian ini adalah pendidikan dan pelatihan (Diklat) (X). Variabel endogen dalam penelitian ini adalah efektivitas organisasi (Y). Variabel mediasi dalam penelitian ini adalah kompetensi pegawai (M).

Populasi dari penelitian ini adalah seluruh PNS di Dinas Perdagangan dan Perindustrian provinsi Bali yang sudah pernah mengikuti pendidikan dan pelatihan (Diklat) yaitu berjumlah 80 pegawai. Metode penentuan sampel yang digunakan dalam penelitian ini adalah Sampel Jenuh dimana semua anggota populasi dijadikan responden penelitian.

Teknik analisis data yang digunakan dalam penelitian ini adalah analisis jalur (Path Analysis). Riduwan dan Kuncoro (2011:2), teknik analisis jalur ini dapat didefinisikan sebagai perluasan dari analisis linier berganda dalam 
memperkirakan hubungan kausalitas antara yang telah ditetapkan berdasarkan teori. Analisis jalur digunakan untuk menentukan hubungan 3 variabel atau lebih dalam mengkorfimasi dan menolak hipotesis.Analisis jalur digunakan untuk menganalisis pola hubungan antar variabel dengan tujuan untuk mengetahui pengaruh langsung maupun tidak langsung variabel eksogen terhadap variabel endogen. Dasar perhitungan koefisian jalur adalah analisis korelasi dan regresi dan dalam perhitungannya menggunakan software dengan program SPSS for windows.

Uji Sobel digunakan dengan menguji kekuatan pengaruh tidak langsung variabel pendidikan dan pelatihan (Diklat) $(\mathrm{X})$ terhadap variabel efektivitas organisasi $\left(\mathrm{Y}_{2}\right)$ melalui variabel kompetensi pegawai $\left(\mathrm{Y}_{1}\right)$. Pengaruh tidak langsung variabel pendidikan dan pelatihan (Diklat) (X) terhadap variabel efektivitas organisasi $\left(\mathrm{Y}_{2}\right)$ melalui variabel kompetensi pegawai $\left(\mathrm{Y}_{1}\right)$ dihitung dengan cara mengalikan koefisien jalur X terhadap $\mathrm{M}$ (a) dengan koefisien jalur M terhadap Y (b) atau ab. Standar error koefisien a dan b ditulis dengan $S_{a}$ dan $S_{b}$, besarnya standar error tidak langsung (indirect effect) $\mathrm{S}_{\mathrm{ab}}$.

\section{HASIL PENELITIAN DAN PEMBAHASAN}

Perhitungan koefisien jalur dilakukan dengan analisis regresi melalui software SPSS 17.0 for Windows, diperoleh hasil yang ditunjukkan pada Tabel 4.

Tabel 4.

Hasil Analisis Jalur Persamaan Regresi 1

\begin{tabular}{|c|c|c|c|c|c|c|}
\hline & \multirow{2}{*}{ Model } & \multicolumn{2}{|c|}{ Unstandardized Coefficients } & \multirow{2}{*}{$\begin{array}{c}\text { Standardized } \\
\text { Coefficients } \\
\text { Beta }\end{array}$} & \multirow{2}{*}{$\mathbf{T}$} & \multirow{2}{*}{ Sig. } \\
\hline & & B & Std. Error & & & \\
\hline \multirow[t]{2}{*}{1} & (Constant) & .654 & .393 & & 1.665 & .100 \\
\hline & Diklat & .819 & .090 & .716 & 9.064 & .000 \\
\hline \multicolumn{2}{|c|}{$\mathrm{R} 1^{2}: .513$} & \multicolumn{2}{|c|}{ F Statistik : 82.164} & Sig F : .000 & & \\
\hline
\end{tabular}


Sumber: Data diolah, 2018

Berdasarkan hasil analisis jalur sub struktur 1 seperti yang disajikan pada

Tabel 4, maka persamaan struktualnya adalah sebagai berikut :

$$
\begin{aligned}
& M=\beta_{1} X+e_{1} \ldots \\
& M=0,716+e_{1}
\end{aligned}
$$

Nilai B1 adalah sebesar 0,716 memiliki arti bahwa pendidikan dan pelatihan (diklat) berpengaruh positif terhadap kompetensi pegawai.

Tabel 5.

\begin{tabular}{|c|c|c|c|c|c|}
\hline \multirow{2}{*}{ Model } & \multicolumn{2}{|c|}{$\begin{array}{l}\text { Unstandardized } \\
\text { Coefficients }\end{array}$} & \multirow{2}{*}{$\begin{array}{c}\text { Standardized } \\
\text { Coefficients } \\
\text { Beta }\end{array}$} & \multirow{2}{*}{$\mathbf{T}$} & \multirow{2}{*}{ Sig. } \\
\hline & B & $\begin{array}{l}\text { Std. } \\
\text { Error }\end{array}$ & & & \\
\hline 1 (Constant) & .706 & .327 & & 2.159 & .034 \\
\hline Diklat & .400 & .106 & .380 & 3.779 & .000 \\
\hline Kompetensi & .433 & .093 & .470 & 4.675 & .000 \\
\hline $\mathrm{R} 2^{2}: .621$ & \multicolumn{2}{|c|}{ F Statistik : 63.089} & Sig. F : .000 & & \\
\hline
\end{tabular}

Hasil Analisis Jalur Persamaan Regresi 2

Sumber: Data diolah, 2018

Berdasarkan hasil analisis jalur sub struktur 2 seperti yang disajikan pada

Tabel 5, maka persamaan strukturalnya adalah sebagai berikut :

$$
\begin{aligned}
& \mathrm{Y}=\beta_{1} \mathrm{X}+\beta_{2} \mathrm{M}+\mathrm{e}_{2} \ldots \ldots \ldots \\
& \mathrm{Y}=0,380 \mathrm{X}+0,470 \mathrm{M}+\mathrm{e}_{2}
\end{aligned}
$$

Nilai B1 adalah sebesar 0,380 memiliki arti bahwa pendidikan dan pelatihan (diklat) berpengaruh positif terhadap efektivitas organisasi.

Nilai B2 adalah sebesar 0,470 memiliki arti bahwa kompetensi pegawai berpengaruh positif terhadap efektivitas organisasi.

Berdasarkan model sub struktur 1 dan sub struktur 2, maka dapat disusun model diagram jalur akhir. Sebelum menyusun model diagram jalur akhir, terlebih dahulu dihitung standar eror sebagai berikut : 


$$
\begin{aligned}
& e=\sqrt{1-k 1^{2}} \ldots \ldots \ldots \ldots \ldots \ldots \ldots \ldots \ldots \ldots \ldots \ldots \\
& e_{1}=\sqrt{1-k 1^{2}}=\sqrt{1-0,513}=0,487
\end{aligned}
$$

(sebesar 48,7\% variabel pendidikan dan pelatihan (diklat) tidak mampu menjelaskan variabel kompetensi pegawai).

$$
\bullet_{2}=\sqrt{1-K 2^{2}}=\sqrt{1-0,621}=0,379
$$

(sebesar 37,9\% variabel pendidikan dan pelatihan (diklat) dan kompetensi pegawai tidak mampu menjelaskan variabel efektivitas organisasi).

Berdasarkan perhitungan pengaruh error (e), didapatkan hasil pengaruh error $\left(e_{1}\right)$ sebesar 0,487 dan pengaruh error $\left(e_{2}\right)$ sebesar 0,379 .

Hasil koefisien determinasi total adalah sebagai berikut :

$$
\begin{aligned}
K_{m}^{2} & =1-\left(\iota_{1}\right)^{2}\left(e_{2}\right)^{2} \ldots \ldots \ldots \ldots \\
& =1-(0,487)^{2}(0,379)^{2} \\
& =1-(0,237)(0,144) \\
& =1-0,034=0,966
\end{aligned}
$$

Nilai determinasi total sebesar 0,966 mempunyai arti bahwa 96,6\% variasi efektivitas organisasi dipengaruhi oleh variasi pendidikan dan pelatihan (diklat) dan kompetensi pegawai, sedangkan sisanya sebesar 3,4\% dijelaskan oleh faktor lain yang tidak dimasukkan ke dalam model.

Berdasarkan hasil analisis pengaruh pendidikan dan pelatihan (diklat) terhadap efektivitas organisasi nilai Sig. $\mathrm{t}$ sebesar 0,000 dengan nilai koefisien beta 0,716 . Nilai Sig. t $0,000<0,05$ mengindikasikan bahwa $H_{0}$ ditolak dan $H_{1}$ diterima. Hasil ini mempunyai arti bahwa Hipotesis diterima yang berarti 
pendidikan dan pelatihan (diklat) berpengaruh positif dan signifikan terhadap kompetensi pegawai.

Berdasarkan hasil analisis pengaruh pendidikan dan pelatihan (diklat) terhadap efektivitas organisasi diperoleh nilai Sig. t sebesar 0,000 dengan nilai koefisien beta 0,380 . Nilai Sig. t $0,000<0,05$ mengindikasikan bahwa bahwa $H_{0}$ ditolak dan $\mathrm{H}_{1}$ diterima. Hasil ini mempunyai arti bahwa Hipotesis diterima yang berarti pendidikan dan pelatihan (diklat) berpengaruh positif dan signifikan terhadap efektivitas organisasi.

Berdasarkan hasil analisis pengaruh kompetensi pegawai terhadap efektivitas organisasi diperoleh nilai Sig. t sebesar 0,000 dengan nilai koefisien beta 0,470 . Nilai Sig. t $0,000<0,05$ mengindikasikan bahwa $H_{0}$ ditolak dan $H_{1}$ diterima. Hasil ini mempunyai arti bahwa Hipotesis diterima yang berarti kompetensi pegawai berpengaruh positif dan signifikan terhadap efektivitas organisasi.

Perhitungan pengaruh antar variabel dirangkum dalam Tabel 4.14 sebagai berikut.

\section{Tabel 6.}

Pengaruh Langsung dan Pengaruh Tidak Langsung serta Pengaruh Total Pendidikan dan Pelatihan (X), Kompetensi Pegawai (M), dan Efektivitas Organisasi (Y)

\begin{tabular}{cccc}
\hline $\begin{array}{c}\text { Pengaruh } \\
\text { Variabel }\end{array}$ & $\begin{array}{c}\text { Pengaruh } \\
\text { Langsung }\end{array}$ & $\begin{array}{c}\text { Pengaruh Tidak Langsung Melalui } \\
\text { Kompetensi Pegawai } \\
(\mathbf{M})=\left(\boldsymbol{\beta}_{\mathbf{1}} \boldsymbol{\beta}_{\mathbf{3}}\right)\end{array}$ & $\begin{array}{c}\text { Pengaruh } \\
\text { Total }\end{array}$ \\
\hline $\mathrm{X} \longrightarrow \mathrm{M}$ & 0,716 & - & 0,716 \\
$\mathrm{X} \longrightarrow \mathrm{Y}$ & 0,380 & 0,337 & 0,717 \\
$\mathrm{M} \longrightarrow \mathrm{Y}$ & 0,470 & - & 0,470
\end{tabular}

Sumber: Data diolah, 2018

Uji sobel dihitung dengan rumus dibawah ini: 


$$
Z=\frac{a}{\sqrt{b^{2} s_{u}^{2}+u^{2} s_{b}^{2}+s_{u}^{2} s_{u}^{2}}}
$$

$$
\operatorname{Sig}=(1-\operatorname{NORMDIST}(Z))+2))
$$

Keterangan:

$$
\begin{array}{ll}
\mathrm{a} & =0,716 \\
\mathrm{~s}_{\mathrm{a}} & =0,090 \\
\mathrm{~b} & =0,470 \\
\mathrm{~s} \mathrm{~b} & =0,093 \\
& Z=\frac{0,716 \cdot 0,480}{\sqrt{0,470^{2} 0,090^{2}+0,716^{2} 0,093^{2}+0,090^{2} 0,093^{2}}}
\end{array}
$$

$$
Z=\frac{0,3365}{\sqrt{0,0018+0,0044+0,0001}}
$$

$$
L=\frac{0,3365}{0,07933}
$$$$
\mathrm{Z}=4,2420
$$

\section{Tabel 7.}

\section{Hasil Uji Sobel}

\begin{tabular}{rc}
\hline Nilai $\mathbf{Z}$ & $\mathbf{Z}$ tabel \\
\hline 4,2420 & 1,96 \\
\hline Sumber: Data diolah, 2018 &
\end{tabular}

Berdasarkan hasil Uji Sobel pada Tabel 7 menunjukkan bahwa hasil tabulasi $\mathrm{Z}=4,2420>1,96$ mengindikasikan bahwa $\mathrm{H}_{0}$ ditolak $\mathrm{H}_{1}$ diterima yang berarti kompetensi pegawai memediasi secara positif dan signifikan pengaruh pendidikan dan pelatihan (diklat) terhadap efektivitas organisasi pada Dinas Perdagangan dan Perindustrian provinsi Bali.

Pengujian hipotesis pada pengaruh pendidikan dan pelatihan (diklat) terhadap kompetensi pegawai menunjukkan bahwa pendidikan dan pelatihan (diklat) berpengaruh positif dan signifikan terhadap kompetensi pegawai. Ini berarti bahwa semakin baik tujuan, peserta, materi, metode, dan narasumber 
pendidikan dan pelatihan (diklat) maka akan meningkatkan kompetensi pegawai pada Dinas Perdagangan dan Perindustrian provinsi Bali.

Hasil penelitian ini mendukung temuan dari Kunartinah dan Sukoco (2010) mengatakan bahwa pendidikan dan pelatihan (Diklat) memiliki pengaruh positif dan signifikan terhadap kompetensi. Purnomo dkk (2016) mengatakan bahwa pendidikan dan pelatihan (Diklat) memiliki pengaruh positif dan signifikan terhadap kompetensi sebesar 80,2\% dan sisanya 19,8\% dipengaruhi oleh variabel lain.

Pengujian hipotesis pada pengaruh pendidikan dan pelatihan (diklat) terhadap efektivitas organisasi menunjukkan bahwa pendidikan dan pelatihan (diklat) berpengaruh positif dan signifikan terhadap efektivitas organisasi. Ini berarti bahwa semakin baik tujuan, peserta, materi, metode, dan narasumber pendidikan dan pelatihan (diklat) maka akan semakin tinggi pula efektivitas organisasi pada Dinas Perdagangan dan Perindustrian provinsi Bali.

Hasil penelitian ini mendukung temuan dari Anike dan Ekwe (2014) yang mengatakan bahwa pendidikan dan pelatihan (diklat) berpengaruh positif signifikan terhadap efektivitas organisasi. Menurut Oktaviana dan Hendriani (2017) mengatakan bahwa pelaksanaan Diklat mempengaruhi keefektifan organisasi secara signifikan, meningkatnya efektivitas organisasi tergantung dari efektif atau tidaknya pelaksanaan Diklat yang dilakukan oleh setiap organisasi atau instansi.

Pengujian hipotesis pada pengaruh kompetensi pegawai terhadap efektivitas organisasi menunjukkan bahwa kompetensi pegawai berpengaruh positif dan 
signifikan terhadap efektivitas organisasi. Ini berarti bahwa setiap pegawai memiliki sikap proaktif, berani mengambil risiko, berorientasi pada masa depan, dan memiliki pengetahuan dan keterampilan yang tinggi maka akan semakin tinggi pula efektivitas organisasi pada Dinas Perdagangan dan Perindustrian provinsi Bali.

Hasil penelitian ini sesuai dengan penelitian Naquin dan Holton (2006)mengatakan bahwa kompetensi pegawai berperan penting dalam meningkatkan kinerja dan efektivitas organisasi. Menurut Nilsson dan Ellstrom (2012) mengatakan bahwa mengembangkan strategi HRD dalam sebuah organisasi adalah kesempatan bagi pegawai untuk memperkaya kompetensi mereka yang berkontribusi secara keseluruhan terhadap efektivitas organisasi.

Hasil Uji Sobel menunjukkan bahwa kompetensi pegawai memediasi pengaruh pendidikan dan pelatihan (diklat) terhadap efektivitas organisasi. Pengujian sebelumnya menunjukkan pengaruh positif dan signifikan pada pendidikan dan pelatihan (diklat) terhadap kompetensi pegawai, pendidikan dan pelatihan (diklat) terhadap efektivitas organisasi, serta kompetensi pegawai terhadap efektivitas organisasi, sehingga dapat disimpulkan bahwa kompetensi pegawai secara parsial memediasi pengaruh pendidikan dan pelatihan (diklat) terhadap efektivitas organisasi pada Dinas Perdagangan dan Perindustrian provinsi Bali.

Hasil penelitian ini didukung oleh Oktaviana dan Hendriani (2017) yang mengatakanbahwa dengan adanyamediasi dari kompetensi, maka efektivitasorganisasi menjadi lebih baik sebagaiakibat dari pelaksanaan diklat 
yangefektif maka peranankompetensi dikatakan mampu menjadi faktormediasi bagi pengaruh diklat terhadapefektivitas organisasi. Menurut Potnuru dan Sahoo (2016) mengatakan bahwa kompetensi bisa menjadi variabel mediasi bagi pengaruh Diklat terhadap efektivitas organisasi karena dengan adanya kompetensi dari pegawai maka efektivitas dalam sebuah organisasi akan berjalan lebih baik sebagai akibat dari pelaksanaan diklat yang efektif. Semakin baik tujuan, peserta, materi, metode, dan narasumber pendidikan dan pelatihan (diklat) maka akan meningkatkan kompetensi pegawai. Melalui pendidikan dan pelatihan (diklat) akan meningkatkan kompetensi pegawai secara tidak langsung efektivitas organisasi pun juga akan ikut meningkat.

Bahasan ini menyajikan tentang hubungan antara temuan penelitian ini dengan kebijakan instansi yang relevan. Implikasi hasil penelitian ini menekankan pada manfaat nyata dari hasil penelitian untuk mempertahankan efektivitas organisasi pada Dinas Perdagangan dan Perindustrian provinsi Bali melalui dukungan pendidikan dan pelatihan (diklat) serta peningkatan kompetensi pegawai pada Dinas Perdagangan dan Perindustrian provinsi Bali. Beberapa implikasi strategis hasil penelitian ini adalah sebagai berikut:

Pertama, bahwa responden sangat setuju dengan program pendidikan dan pelatihan (diklat) akan meningkatkan efektivitas organisasi. Indikator dari pendidikan dan pelatihan (diklat) seperti tujuan, peserta, materi, metode, dan narasumber sangat diperlukan dalam mempertahankan efektivitas organisasi. Dengan melaksanakan program pendidikan dan pelatihan (diklat) secara berkala maka akan berdampak terhadap efektivitas dalam organisasi. Berdasarkan 
informasi tersebut, penting bagi instansi untuk melaksankan program pendidikan dan pelatihan (diklat) secara berkala.

Kedua, meningkatnya kompetensi pegawai dalam sebuah instansi juga dapat meningkatkan efektivitas dalam organisasi. Pernyataan responden tentang saya tertarik untuk mempelajari sesuatu yang baru memiliki rata-rata paling tertinggi. Hal ini menunjukkan bahwa setiap pegawai di Dinas Perdagangan dan Perindustrian provinsi Bali tertarik untuk mempelajari sesuatu yang baru terutama yang berkaitan dengan teknologi dan informasi. Menurut responden kebutuhan akan hal tersebut sangat membantu akan penyelesaian pekerjaan yang secara langsung akan berdampak pada efektivitas organisasi.

Implikasi yang ketiga, pernyataan responden tentang Dinas Perdagangan dan Perindustrian provinsi Bali memiliki tujuan akhir yang jelas memiliki ratarata paling tertinggi. Ini menunjukkan bahwa tujuan organisasi harus dirumuskan secara jelas dan realistis sehingga bisa dijadikan pedoman dalam menyusun program-program dalam instansi salah satunya yaitu program pendidikan dan pelatihan (diklat). Peran program pendidikan dan pelatihan (diklat) akan meningkatkan efektivitas organisasi yang didukung oleh kompetensi pegawai yang tinggi. Hal ini menjadi pertimbangan bagi pihak organisasi atau instansi untuk bisa mempertahankan kompetensi dari setiap pegawai melalui program pendidikan dan pelatihan (diklat) agar efektivitas dalam organisasi tidak mengalami penurunan.

Adapun keterbatasan dalam penelitian ini adalah penelitian ini hanya dilakukan pada satu SKPD pemerintahan provinsi Bali sehingga tidak bisa 
menggeneralisir kondisi yang ada pada SKPD lainnya di pemerintahan provinsi bali serta variabel-variabel yang digunakan pada penelitian ini hanya terbatas pada variabel pendidikan dan pelatihan (diklat) dan kompetensi pegawai dalam mengukur efektivitas organisasi.

\section{SIMPULAN DAN SARAN}

Berdasarkan hasil pembahasan penelitian yang telah dilakukan, maka dapat disimpulkan bahwa Pendidikan dan pelatihan (diklat) berpengaruh positif dan signifikan terhadap kompetensi pegawai. Ini berarti bahwa semakin baik tujuan, peserta, materi, metode, dan narasumber pendidikan dan pelatihan (diklat) maka akan meningkatkan kompetensi pegawai pada Dinas Perdagangan dan Perindustrian provinsi Bali.

Pendidikan dan pelatihan (diklat) berpengaruh positif dan signifikan terhadap efektivitas organisasi. Ini berarti bahwa semakin baik tujuan, peserta, materi, metode, dan narasumber pendidikan dan pelatihan (diklat) maka akan semakin tinggi pula efektivitas organisasi pada Dinas Perdagangan dan Perindustrian provinsi Bali.

Kompetensi Pegawai berpengaruh positif dan signifikan terhadap efektivitas organisasi. Ini berarti bahwa setiap pegawai memiliki sikap proaktif, berani mengambil risiko, berorientasi pada masa depan, dan memiliki pengetahuan dan keterampilan yang tinggi maka akan semakin tinggi pula efektivitas organisasi pada Dinas Perdagangan dan Perindustrian provinsi Bali. 
Kompetensi pegawai berpengaruh positif dan signifikan memediasi pengaruh pendidikan dan pelatihan (diklat) terhadap efektivitas organisasi pada Dinas Perdagangan dan Perindustrian provinsi Bali.

Saran yang dapat diberikan berdasarkan kesimpulan yang didapat adalah untuk meningkatkan efektivitas organisasi, hendaknya Dinas Perdagangan dan Perindustrian provinsi Bali melakukan evaluasi secara berkala sehingga bisa mencapai target yang sudah ditentukan.

Dinas Perdagangan dan Perindustrian provinsi Bali hendaknya melakukan evaluasi secara berkala yaitu minimal penialaian dilakukan pertriwulan terutama penilaian terhadap setiap proses kinerja pegawai.

Dalam melaksanakan pendidikan dan pelatihan (diklat) bagi pegawai Dinas Perdagangan dan Perindustrian provinsi Bali hendaknya pihak penyelenggara selalu menyesuaikan media yang digunakan dengan kebutuhan peserta diklat. Pendidikan dan pelatihan (diklat) hendaknya dilaksanakan karena sesuai dengan kebutuhan pegawai bukan karena pegawai tersebut sudah memenuhi syarat.

Dinas hendaknya selalu memotivasi pegawainya untuk bersikap inisiatif agar pegawai terbiasa untuk mengerjakan tugas tanpa menunggu perintah dari atasan. Dinas Perdagangan dan Perindustrian provinsi Bali hendaknya memberikan pendidikan dan pelatihan yang sesuai bagi pegawai agar setiap pegawai bisa menyelesaikan tugas yang diberikan dan mengahadapi setiap tantangan yang ada di dalam pekerjaan mereka.

Bagi peneliti berikutnya, untuk meningkatkan kualitas penelitian sebaiknya memperluas ruang lingkup penelitian, dan menambahkan beberapa variabel yang 
mempengaruhi efektivitas organisasi seperti motivasi berprestasi, pengembangan karir, sehingga mampu meningkatkan efektivitas organisasi terutama pada Dinas Perdagangan dan Perindustrian provinsi Bali.

\section{REFERENSI}

Anike, Happiness O.F. and Michael C. Ekwe. (2014). Impact of Training and Development on Organizational Effectiveness: Evidence from Selected Public Sector Organizations in Nigeria. European Journal of Business and Management. 6(29): h: 66-75.

Ardana, I Komang, Mujiati, Utama. (2012). Manajemen Sumber Daya Manusia. Penerbit Graha Ilmu, Yogyakarta.

Cartwright, S, and Helen, Baron. (2002). Culture and organizational effectiveness. Organizational Effectiveness: The Role of Psychology. 30(2): h: 181-200.

Darsono dan T. Siswandoko, (2011). Manajemen Sumber Daya ManusiaAbad 21. Jakarta: Penerbit Nusantara Consulting.

Fernandez Diaz, M., Lopez-Cabrales, A and Valle-Cabrera, R. (2014). A contingent approach to the role of human capital and competencies on firm strategy. Business Research Quarterly. 17(3) : h: 205-222.

Handoko, T. Hani. (2001). Manajemen Personalia dan Sumber Daya Manusia. Yogyakarta: BPFE Yogyakarta.

Irianto, Yusuf. (2001). Prinsip-prinsip Dasar Manajemen Pelatihan: Dari Analisis Kebutuhan Sampai Evaluasi Program Pelatihan. Surabaya: Insan Cendekia.

Jehanzeb, K. and N.A, Bashir. (2013). Training and Development Program and its Benefits to Employee and Organization: A Conceptual Study. European Journal of Business and Management. 5(2) : h: 243- 252.

Kunartinah dan Fajar Sukoco. (2010). Pengaruh Pendidikan dan Pelatihan, Pembelajaran Organisasi Terhadap Kinerja Dengan Kompetensi Sebagai Mediasi. Jurnal Bisnis dan Ekonomi (JBE). 17(1): h:74 - 84

Lastanti, Hexana Sri. (2005). Tinjauan Terhadap Kompetensi dan Independensi Akuntan. Jurnal Media Riset Akuntansi, Auditing \& Informasi. 5(1). h:85-97

Lawler, Edward and Ledford, G.R. (1997). New approaches to organizing: competencies, capabilities and the decline of the bureaucratic model.CreatingTomorrow's Organization: A Handbook for Future Research in Organizational Behavior.

Lee, Y.T. (2010). Exploring high performer's required competencies. Expert Systems with Applications. 37(1): h: 434-439 
Leinweber, S. (2013). Stage 3: competence management, in Meifert, M.T. Strategic Human Resource Development, Springer Science plus Business Media, Dordrecht. 36(1): h: 109-133.

Mangkunegara, Anwar Prabu. (2009). Manajemen Sumber Daya Manusia Perusahaan. Bandung: Remaja Rosdakarya.

Manullang M. (2008). Manajemen Sumber Daya Manusia, Edisi I. Yogyakarta: BPFE.

Markovic, M.R. (2008). Managing the organizational change and culture in the age of Globalization. Journal of Business Economics and Management. 9(1) : h: 3-11.

McNamara, C. (2010). Employee Training and Development: Reasons and

Benefits.Free Management Library.

Mohyi, Ach. (2012). Teori dan perilaku organisasi: Membentuk, mengelola, mendeteksi kepribadian, efektifitas dan mengembangan organisasi. Malang: Universitas Muhammadiyah.

Moses, Melmambessy. (2011). Pengaruh Pendidikan dan Pelatihan Penjenjangan Terhadap Prestasi Kerja Pegawai Pada Dinas Koperasi dan UKM Kota Jayapura. Jurnal Analisis Manajemen. 5(2) : h: 74-75

Mursidi. (2009). Pengaruh Pendidikan dan Pelatihan Terhadap Kinerja Karyawan. Malang: Universitas Muhammadiyah

Nair, Vigi V. (2007). Behavioural Competency and Organizational Performance.International Journal ofResearch in Management, Economicsand Commerce. 1(2): h:. 255-264.

Naquin, S.S. and E.F Holton. (2006). Leadership and managerial competency models: a simplified process and resulting model. Advances in Developing Human Resources. 8 (2): h: 144-165.

Nilsson, S. and Ellstrom, P.E. (2012). Employability and talent management: challenges for HRD practices. European Journal of Training and Development. 36(1): h: 26-45.

Nurmanah, E. (2009). Pengaruh Kompetensi Pegawai dan Budaya Organisasi Terhadap Efektivitas Organisasi Biro Kepegawaian Sekretariat Jenderal Departemen Hukum dan HAM Republik Indonesia. Tesis Universitas Indonesia. 5(3). h:121-130

Oktaviana, Suci dan Susi Hendriani. (2017). Pengaruh Kepemimpinan, Pendidikan dan Pelatihan Terhadap Efektivitas Organisasi Melalui Kompetensi Pada Pegawai Negeri Sipil di Biro Umum dan Dinas Pendapatan Daerah Provinsi Riau. Jurnal Tepak Manajemen Bisnis. 9(3). 180-197. 
Parulian, Hutapea dan Nurianna Thoha, (2008). Kompetensi Plus. Jakarta: Gramedia Pustaka Utama.

Potnuru, Krishna Rama Gupta. and Chandan Kumar Sahoo. (2016). HRD interventions, employee competencies and organizational effectiveness: an empirical study. European Journal of Training and Development. Vol. 40(5): h: 345-365

Priansa, Donni Juni. (2014). Perencanaan \& Pengembangan SDM. Bandung: Alfabeta

Purnomo Danang., I Putu Sudana dan Saraswan Mananda. (2016). Pengaruh pendidikan dan pelatihan terhadap kompetensi serta dampaknya pada kinerja pramuwisata bali. Jurnal Institut Pengajian Tinggi Awam. 4(2) : h: 51-57

Rauner, F., Heinemann, L., Maurer, A., Haasler, B., Edwien, B. and Martens, T. (2013). Measuring professional competence, Competence Development and Assessment in TVET (COMET). Dordrecht: Springer Science plus Business Media.

Riduwan dan Engkos Ahmad Kuncoro. (2011). Cara Menggunakan dan Memaknai Analisis Jalur(Path Analysis). Bandung: Alfabeta

Subkhi, Akhmad dan Mohammad Jauhar. (2013). Pengantar Teori dan Perilaku Organisasi. Jakarta: Prestasi Pustaka.

Sujanto, Alex. (2009). Rekrutmen dan Seleksi Berbasis Kompetensi: Tantangan Dalam Pemenuhan Kebutuhan Tenaga Kerja Pada Knowledge Society. Journal Amik JTC Semarang. 5(1): h:8-15.

Sutrisno, Edy. (2010). Budaya Organisasi. Jakarta : Penerbit Kencana.

Tarique, Ibraiz and Randall S. Schuler. 2010. Global talent management: literature review, integrative framework, and suggestions for further research. Journal of World Business. 45(2): h: 122-133.

Whitfield, Gwendolyn and Robert Landeros. (2006). Supplier diversity effectiveness: does organizational culture really matter?. The Journal of Supply Chain Management: A Global Review ofPurchasing and Supply. 42(4): h: 16-28.

Yoder, Dale. (2000). Personel Management and Industrial Relation. New Delhi: Practice Hall of India Private Limited.

Yuniarti, Eka Pratiwi., Bambang Swasto Sunuharyo dan Hamidah Nayati Utami. (2013). Pengaruh On The Job Training \& Off The Job Training Terhadap Kinerja Karyawan. Malang : Fakultas Ilmu Administrasi, Universitas Brawijaya. 4 (2): h: 31-45 